\title{
Public Administration entities VS. SPECIFIC (UNTYPICAL) ENTITIES'IN POLISh ADMINISTRATIVE LAW SYSTEM
}

\author{
Paulina Bieś-Srokosz ${ }^{1}$
}

\section{Jan Dlugosz Universty in Czestochowa, Institute of Administration, Poland email: p.bies@ajd.czest.pl}

BIEŚ-SROKOSZ, Paulina. Public administration entities vs. specific (untypical) entities' in Polish administrative law system. International and Comparative Law Review, 2014, Vol. 14., No. 1, pp. 79-88. DOI: 10.1515/iclr-2016-0046.

\begin{abstract}
The political changes in Poland that took place at the end of the 20th century contributed to the establishment of new organizational forms of public administration entities. Their objective was to adapt administration, its operations, and its organizational forms to perform new public tasks in the area of economy. The entities operating within those new organizational forms were in conflict with the traditional notion of public administration entity. The main objective of this article is the analysis of legal status of each specific entities of public administration and to draw attention to their eclectic legal character.
\end{abstract}

Keywords: Polish public administration entities, Polish specific public administration entities, Polish administrative law system, analysis of Polish administrative law

The majority of relevant notions and institutions present in Polish administrative law system need to be approached in a new way, for the current approach is to certain extent out-of-date and may raise doubts. The same holds for the notion of public administration entity. Such a state of affairs may be caused by the structural transformations of the state which continually expands the range of tasks to perform. It may also be a result of the formation of new organizational forms. The Polish theory lacks an unambiguous definition of public administration entity. In the literature on the subject one can find numerous approaches to "public administration entity". According to W. Dawidowicz, public administration entity is an entity formed (created) and equipped by a legislative act with a number of competences for performance of administrative tasks, being at the same time a starting point for the establishment of proper organizational structure necessary to perform those tasks. M. Stahl points out that numerous representatives of the theor $y^{2}$ consider the state the elementary public adminis-

1 Assistant/master of administration, Jan Dlugosz Universty in Czestochowa, Institute of Administration, Poland.

2 T.Rabska,Podstawowepojęciaorganizacjiadministracji,(w:)Systemprawaadministracyjnego, 
tration entity. ${ }^{3}$ It stems from the legal personality of the state and the fact that it is represented by its own organs exercising state power. That power is always of state nature. The state can devolve some power to public administration entities as well as to non-public entities which are legally bound to perform public tasks. Nevertheless, it is organs of those entities that exercise power on behalf of the state and other entities. When it comes to public administration, its organs exercise administrative power pursuant to administrative law provisions. ${ }^{4}$ It is therefore an inherent feature of public administration entities and activities performed by the organs of those entities. ${ }^{5}$

However, in the $19^{\text {th }}$ and $20^{\text {th }}$ centuries the scope of the notion of public administration entity was expanded to include not only public administration organs but also entities equipped with legal personality and performing public administration tasks. According to M. Stahl, "the employment of the notion of public administration entity stemmed from legal reality and the search for forms of decentralization of public tasks while with the increase of the number of state tasks and activities the deconcentration formula was not sufficient anymore and it was necessary to form independent organizational units equipped with separate legal personality". 6 Apart from the notion "public administration entity", there are other similar notions in the literature: public entity ${ }^{7}$, public law entity ${ }^{8}$, administration entity ${ }^{9}$

t. I, red. J. Starościak, Wrocław 1977, pp. 270 i n.; H. Maurer, Ogólne prawo administracyjne. Allgemeines Verwaltungsrecht, red. K. Nowacki, Wrocław 2003, pp. 230 i n.

3 M. Stahl, Zagadnienia ogólne, (w:) Podmioty administrujące, System prawa administracyjnego, t. VI, red. R. Hausner, Z. Niewiadomski, A. Wróbel, Warszawa 2011, p. 12.

4 J. Borkowski, Pojęcie władztwa administracyjnego, Acta Universitatis Wratislaviensis no 167, „Przegląd Prawa i Administracji” no 31, Wrocław 1972, pp. 43 i n.; Z. Pulka, Władztwo administracyjne jako szczególna postać władzy państwowej, Acta Universitatis Wratislaviensis no 1313, Prawo CCVI, Wrocław 1992, pp. 137 i n.; J. Jendrośka, Zagadnienia prawne wykonania aktu administracyjnego, Wrocław 1963, pp. 15 i n.

5 Look at: S. Kasznica, Polskie prawo administracyjne. Pojęcia i instytucje zasadnicze, Warszawa 1943, p. 38.

6 M. Stahl, Zagadnienia ogólne, op. cit., p. 15.

7 This term is a wider than the definition of the concept of entity administration. The concept of a public entity is in particular in the acts on public-private partnership and the operations of the entities performing public tasks.

8 This term of a public body is narrower than the concept of scope as an administrative entity. This is due to the list of entities that belong to him. First of all, the basis for determining the public body is the nature of the standards of its establishment and the functions performed.

9 The administration entity belongs to the category of "public law entities" which perform public tasks of administrative nature. According to the theory, each entity obliged under statutory provisions to perform public administration tasks is considered an administration entity. "Public law entity" has been defined in Article 2, Paragraph 1 Subparagraph 4 of the Directive 2014/24/EU of the European Parliament and of the Council of 26 February 2014 on public procurement and repealing Directive 2004/18/EC (Official Journal of the European Union 2014, L 94/65) and in Article 3 Paragraph 4 of the Directive 2014/25/EU of the European Parliament and of the Council of 26 February 2014 on procurement by entities operating in the water, energy, transport and postal services sectors and repealing 
and administering entity ${ }^{10}$. Yet, further parts of the paper will be devoted only to public administration entities and their characteristic features.

The essential constituents of the notion of public administration entity are: performance of public administration tasks in the public interest, and acting under statutory provisions. It is a wide notion covering all organizational forms of performing public tasks. For this reason, it is not the legal character of a unit's organizational form but the performance of public tasks in the public interest that plays an important role. It must be noted that public administration entities have rights and obligations of administrative nature, stemming from statutory regulations. When viewed form that angle, the notion covers the following entities: government administration entities, decentralized administration entities, and authorized private law entities.

An organizational unit can be categorized as a public administration entity if its exclusive or main activity involves performing public tasks. It is a sine qua non condition. Thus the entities formed pursuant to private law (e.g. limited liability companies and joint stock companies), or the entities in which majority interest belongs to public law institutions, may be classified as public administration entities if they meet the aforementioned sine qua non condition. It is however important to pay attention to the problem of how to classify a given organizational unit under a given group of public administration entities. One must bear in mind all conditions determining the participation of those units in performance of public administration tasks in a wider and wider scope. All in all, one should consider the notion of public administration entity in the strict sense limiting the range of entities to the ones functioning and acting pursuant to public law.

Taking into account the diverse standpoints advocated by theoreticians, it must be noted that some of them consider "administering entity" a more suitable term. It stems from the fact that on the doctrinal plane the term has become an equivalent of the notion of public administration system in the functional sense. ${ }^{11}$ The term "administering entity" encompasses a group of entities included among public administration apparatus and situated outside the structure

Directive 2004/17/EC (Official Journal of the European Union 2014, L 94/243). "Public law entities (bodies)" means bodies that have all of the following characteristics: a) they are established for the specific purpose of meeting needs in the general interest, not having an industrial or commercial character; b) they have legal personality; and c) they are financed, for the most part, by the State, regional or local authorities, or by other bodies governed by public law; or are subject to management supervision by those authorities or bodies; or which have an administrative, managerial or supervisory board, more than half of whose members are appointed by the State, regional or local authorities, or by other bodies governed by public law.

10 The term of the administrative entity to be understood class of persons performing public administrative functions in the subjective sense.

11 M. Stahl, Zagadnienia ogólne, op. cit, p. 25. 
of the administration, regardless of whether they perform functions of ruling nature or otherwise. However, it must be pointed out that the list of those entities is non-exhaustive. The diversity of administering entities leads to chaos within administrative law system, which in turn leads to problems that are at times difficult to solve. ${ }^{12}$ For this reason, attention must be paid to the fact that the legislator continuously creates new notions as well as new organizational forms classifying them as "untypical public administration entities", for they do not fit within the traditional notion of public administration entity due to their legal structure.

Again, it must be stressed that the notion of public administration entity, as well as the conditions for considering an entity one, depend on several factors. Firstly, one must decide whether to define a public administration entity in the wide or in the strict sense. Secondly, a given entity should be considered a public administration entity if it is a part of public administration apparatus and meets essential conditions. Using the phrase 'meets essential conditions' it must be borne in mind that the public administration entity performs public tasks in the public interest, makes use of power while performing public tasks, is formed in compliance with a legislative act or other normative act, and is subject to supervision by state organs.

It is stressed in the literature that the continuous changes of the society's needs in modern states contribute to the increase of the number of tasks of diverse legal nature. As a consequence, public administration is faced with the problem of how to perform those tasks. The problem entails numerous political, organizational, praxeological, personnel, and legal-structural issues. The latter deserves a closer look, for it concerns organizational forms of performing public tasks, and adaptation of those forms to new needs. ${ }^{13}$ The subjective catalogue of organizational units performing public administration tasks is continuously updated. It stems from the formation of new organizational units that do not fit within the traditional notion of public administration entity.

As it has already been said, the political changes that took place at the end of the $20^{\text {th }}$ century contributed to the establishment of new organizational forms of public administration entities. Their objective was to adapt administration, its operations, and its organizational forms to perform new public tasks in the area of economy. The entities operating within those new organizational forms were in conflict with the traditional notion of public administration entity. They include public foundations, funds, government agencies ${ }^{14}$, the National Bank of Poland, and the Polish Post, among others.

12 Look at: J. Zimmermann, Prawo administracyjne, Kraków 2006, pp. 103 i n.

13 J. Jagielski, M. Wierzbowski, A. Wiktorowska, Nietypowe podmioty administrujace - kilka refleksji na tle organizacyjnych form wykonywania zadań publicznych, (w:) Podmioty administracji publicznej i prawne formy ich działania. Studia i materiały z konferencji jubileuszowej Profesora Eugeniusza Ochendowskiego, Toruń 2005, p. 203.

14 Also called: administrative agencies, state agencies, and government agencies economies. 
The discussion of specific public administration entities will be focused first on the National Bank of Poland's position within the legal system. That entity is included among specific entities, for on the one hand it displays features of an economic entity, while on the other it is the state's central bank which is at the same time the bank authorised to issue banknotes, and the bank of other banks. ${ }^{15}$ Pursuant to Article 52 Paragraph 4 of the Act on the National Bank of Poland, the Bank can possess and trade in foreign currencies on its own behalf, on its own account, and on account of other entities. ${ }^{16}$ The bank is also allowed to perform activities concerning foreign currency trading nationally and abroad, giving and taking foreign loans, granting and taking bank sureties and guarantees in international trade.

Pursuant to the constitutional regulations, the central Bank is independent of the Council of Ministers. Furthermore, the constitution regulates the structure of the Bank's organs and the mechanisms of their actions in accordance with the constitutional principle of separation, balance and cooperation of public authorities functioning as organs of executive power. The complexity of the Bank's legal position is also reflected in its essential objective, that is sustaining stable prices ${ }^{17}$ along with supporting the economic policy of the government. ${ }^{18}$ The latter cannot however restrict the former. The fact that the chairman of the Bank is not politically accountable to legislative authorities cannot be considered one of the constituting features of public administration apparatus. ${ }^{19}$ The Bank's independence of executive authorities stems from the fact that its reports are examined by an independent expert auditor appointed by the Monetary Policy Council. What is more, the chairman of the Bank is appointed by the lower house of the parliament on a proposal from the President of Poland. The chairman and other organs of the bank are appointed to a six-year term. They can be dismissed only for so called personal reasons.

Under the provisions of Article 227 of the Polish Constitution, the autonomy of the Bank manifests itself in its exclusive competence for issuing money and the implementation of monetary policy. It must be stressed that, when it comes to the actions undertaken to perform its tasks, the Bank operates within the framework of public and private law. On the one hand, as the bank of banks, the Bank sets by means of a normative act the percent rate of cash deposits obligatorily held by banks as reserves. On the other hand, the Bank enters into civil

15 Look at: H. Gronkiewicz-Waltz, Bank centralny w rynkowym systemie gospodarczym, „Prawo Bankowe” 1994, no 3, p. 28; J. Pietrewicz, Bank centralny w polskiej gospodarce rynkowej, „Bank i Kredyt” 1994, no 6, p. 9.

16 The Act of $29^{\text {th }}$ August 1997 on Polish National Bank (Journal Laws of 2013, item 908, as. amended.).

17 The stabilization of inflation at a low and level optimal for the economy.

18 Article 3 Paragraph 1 of the Act on the National Bank of Poland.

19 Look at: the article 9 paragraph 1. 
law contracts with banks to grant them refinancing loans. ${ }^{20}$ As stressed by $\mathrm{H}$. Gronkiewicz-Waltz ${ }^{21}$, the National Bank of Poland, though employing private law forms of operation, performs public functions. Hence it can be said that public law functions of the Bank are more important than other functions.

The theory of Polish administrative law describes organizational units the formation of which depends on the capital factor. They include entities performing tasks of administrative nature like for instance public law foundations and funds. It must be stressed that the word "foundation" does not stand for a uniform legal category. In the theory there are private law foundations, public law foundations, and public foundations. Public law foundations are public administration entities characterized by specific legal character. The literature ${ }^{22}$ describes them as decentralized public administration entities, whereas during the interwar ${ }^{23}$ period they were being established by way of public law acts and described as property equipped with legal personality and intended for performance of concrete public administration tasks. The distinguishing features of public law foundations include: formation by way of a legislative act or on the basis of statutory authorisation, and capital and property provided by the state to perform public tasks. ${ }^{24}$

Currently, there are three foundations of that kind: National Ossoliński Institute, Public Opinion Research Center, and Kórnik Institute. Each one of those public law foundations has been established by way of a given legislative act ${ }^{25}$, and performs its public tasks pursuant to the provisions of that act. It must be stressed however that those entities acquire legal personality not under their acts but with the entry to National Court Register. According to H. Cioch, the provisions of the Act on foundations are not applicable to public law foundations

20 H. Gronkiewicz-Waltz, Pozycja prawna Narodowego Banku Polskiego, (w:) Prawo gospodarcze. Zagadnienia administracyjnoprawne, red. H. Gronkiewicz-Waltz, M. Wierzbowskiego, Warszawa 2009, p. 104.

21 Ibidem.

22 More about foundations of public law wrote: H. Cioch, Prawo fundacyjne, Warszawa 2002; idem, Fundacja - Zakład Narodowy imienia Ossolińskich jako fundacja prawa publicznego, „Państwo i Prawo” 2000, no 4; idem, O potrzebie dokonania zmian w polskim prawie fundacyjnym, „Gdańskie Studia Prawnicze” 1999, no 5; E. Ochendowski, Fundacja prawa publicznego - nowy podmiot administracji, (w:) Gospodarka. Administracja. Samorząd. Praca poświęcona 55-leciu pracy twórczej Profesor Teresy Rabskiej, red. H. Olszewski, B. Popowska, Poznań 1997, pp. 335 i n.

23 W.E. Rappé, Fundacje, (w:) Encyklopedia nauk politycznych, t. II, Warszawa 1937; idem, O „publiczno-prawnej” fundacji w ustawodawstwie polskim, Lwów 1930.

24 E. Ochendowski, Fundacja prawa publicznego, op. cit., t. II, p. 360.

25 The Act of $5^{\text {th }}$ January 1995 on the foundation - Department of National Ossoliński (Journal Laws of 1995, No. 23, item. 121, as amended); Act of $20^{\text {th }}$ February 1997 on the Foundation - Public Opinion Research Center (Journal. Laws of 1997, No. 30, item. 163, as amended); Act of 18th September 2001on the foundation - Betting Kórnickie (Journal Laws of 2001, No. 130, item. 1451). 
established under separate acts. ${ }^{26}$ The aforementioned provisions concern private law foundations established by way of foundational acts. ${ }^{27}$ It is justifiable therefore to question such regulations, for the discussed entities should acquire legal personality by way of a given legislative act. They perform public tasks falling within the scope of tasks generally stipulated by the act on foundations. Supervision over the operations and tasks performed by those entities is exercised by organs of government administration, that is the competent minister and the Prime Minister (as regards Public Opinion Research Center). Simultaneously, those organs are authorised to equip foundations with statutes, and to revoke decisions issued by organs of foundations (if those decisions are in conflict with legal regulations or a given statute).

As far as funds are concerned, they display features of financial institutions. They own separate public property and perform public tasks devolved upon them by a legislative act. One of the basic problems here is to determine the legal status of funds as decentralized public entities. Even the word "fund" is ambiguous itself. The theory says about government and self-government (regional) special purpose funds. Their statutorily stipulated tasks and operations include management with isolated financial resources. They are equipped with legal personality and statutorily stipulated organizational structure. As stated in the literature, special purpose funds classified as public institutes and decentralized public entities include: Bank Guarantee Fund ${ }^{28}$, Guaranteed Employee Benefits Fund ${ }^{29}$, Labour Fund ${ }^{30}$, and Funds for Environmental Protection ${ }^{31}$ and Water Management. It must be noted, however, that the tasks devolved upon those entities are characterized by a rich diversity. ${ }^{32}$ On the one hand, they can take actions

26 H. Cioch, O potrzebie dokonania zmian w polskim prawie fundacyjnym, „Gdańskie Studia Prawnicze" 1999, no 5.

27 M. Stahl, Inne podmioty administrujace, (w:) Podmioty administrujace, System prawa administracyjnego, t. VI, red. R. Hausner, Z. Niewiadomski, A. Wróbel, Warszawa 2011, p. 519.

28 In the Act of $14^{\text {th }}$ December 1994 on Banking Guarantee Fund (Journal. Laws of 2009, No. 84, item. 711, as amended). In accordance with the article $3 \mathrm{a}$ objective of the Fund is to work for the stability of the domestic financial system, in particular by ensuring the functioning of the mandatory deposit protection scheme, assistance and support, and providing or performing recapitalization guarantee under the terms of the Act.

29 From the $1^{\text {st }}$ January 2012 the Guaranteed Employee Benefits Fund became a state fund within the meaning of the Act of $27^{\text {th }}$ August 2009 on Public Finance (Journal Laws of 2009, No. 157, item. 1240, as amended), then u.f.p., which introduced new rules for action and change the status (loss of legal personality) of state funds.

30 The Act of $6^{\text {th }}$ April 1984 about foundations (Journal Laws No. 21, item. 97, as amended).

31 Fundamentals of the functioning of their business are set out in the Act of $27^{\text {th }}$ April 2001 on Environmental Protection Law (Journal Laws of 2013, item. 1232, as amended).

32 J. Jagielski, M. Wierzbowski, A. Wiktorowska, Nietypowe podmioty administrujace - kilka refleksji na tle organizacyjnych form wykonywania zadań publicznych, (w:) Podmioty administracji publicznej..., op. cit., p. 211. 
designed to co-finance investment projects and to finance retraining courses. On the other, they can disburse benefits to entitled entities.

However, in 2009 the amendments to the Act on public finance brought changes concerning the legal status of state special purpose funds. Under the provisions of the Act, a special purpose fund is established pursuant to a separate act in the form of an isolated bank account. The account is managed by a minister or an organ designated by that act. Yet another significant amendment to the Act on public finance deprived special purpose funds of legal personality. Both in the theory of financial law and in judicial decisions one can find the view that such a diversity of funds leads to disintegration of public finance economy, and significantly complicates the processes of accumulation and expenditure of public money. In the view of the Constitutional Tribunal of Poland, the establishment of special purpose funds hinders budgetary management, which in turn makes it impossible to administer with public money in a flexible and efficient way. ${ }^{33}$

When it comes to the Bank Guarantee Fund, it must be stressed that as a specific public administration entity it performs two basic functions. Firstly, it guarantees the depositors of bankrupt banks disbursement of their money up to the maximum amount stipulated in the Act on Bank Guarantee Fund. Secondly, the Fund provides financial aid to the banks covered by the deposit guarantee scheme. The Fund has its public mission which involves actions for ensuring the safety of the clients of the banks covered by the deposit guarantee scheme. Actions for ensuring stability of banks and the whole banking sector, and actions for building trust for the banking system among citizens. The Fund operates through its organs, that is the Council and the Management Board. The latter represents the Fund, performs tasks concerning giving aid, and deals with guarantee issues. The supervision over the operations performed by the Fund is exercised by the Minister of Finance in accordance with the criteria of legality and compliance of undertaken actions with the statute. ${ }^{34}$

The Bank Guarantee Fund operates in compliance with the risk minimizer ${ }^{35}$ rule according to which the Fund, apart from its essential activity, can provide aid to the banks threatened with bankruptcy. The main objective of the Fund is to guarantee the deposits made by natural and juridical persons in the banks covered by the scheme. The actions undertaken by that entity are performed in the public interest, which displays itself in factual and legal actions aimed at increasing public trust for the banking system.

33 The judgment of the Constitutional Court of 21th February 2005.

34 Look at: R. Sura, Bankowy Fundusz Gwarancyjny jako podmiot administrujący, Lublin 2013, p. 184.

35 This principle consists in the fact that in addition to the guarantee function is granted financial assistance to banks at risk of bankruptcy. 
The Polish Post is another entity characterized by specific legal status. Its operations involve conducting business activity that consists in providing postal services nationally and abroad. The activity called "postal activity" is regulated in the Act of $23^{\text {rd }}$ November 2012 on Postal $\mathrm{Law}^{36}$. Postal services involve a variety of commercial activities performed jointly or separately which include receiving, sorting and delivering addressed mail and unaddressed advertising mail, translocating parcels and unaddressed advertising mail, sending mail by means of electronic communication if at the stage of registration, translocation or delivery it takes the physical form of letter mail; running exchange offices enabling the clients to send and receive correspondence, and to place and cash postal orders.

Postal activity is regulated activity as stipulated in the provisions of the Act of $2^{\text {nd }}$ July 2004 on Freedom of Conducting Business Activity (Journal of Laws from 2013, item 672). For that reason, it is required to be entered in the postal operators register. It is not however necessary to register: postal activity that consists in collecting, sorting, translocating and delivering unaddressed advertising mail; activity conducted by a postal agent acting under a contract of agency concluded with a postal operator; and postal activity conducted by a subcontractor on behalf of a postal operator under a contract concluded in written form. The organ responsible for registering is the President of the Office of Electronic Communications. Under the legal situation as of today, the Polish Post performs the function of an "appointed operator" only throughout the transition period lasting up to the end of 2015. After that time, the Polish Post will have to take part in competition for postal services held by the President of the Office of Electronic Communications.

It should be pointed out that postal services market is becoming more and more crowded as there are new independent postal operators. The Polish Post is not well prepared for that situation. It is believed that the Polish Post ${ }^{37}$ will become more competitive and provide services of higher quality if it is transformed into sole-shareholder joint-stock company of the State Treasury ${ }^{38}$.

The establishment of new forms of organizational units intended for satisfying social needs by the state forces the legislator to employ untypical organizational and legal forms. Those specific entities include also agencies which can serve as an example of adaptation of organizational forms of administration to constantly changing public tasks. The lack of common and uniform legal regulations concerning all agencies stems form the existing classification of those entities according to their legal nature. They can act as civil as well as public law entities.

36 The Act of $12^{\text {th }}$ June 2003 on Postal Law (Journal Laws of 2012, item. 1529).

37 The Act of $5^{\text {th }}$ September 2008 on the commercialization of public utilities "Mail Poland" (Journal Laws of 2008, No. 164, item. 1027).

38 The position represented by the Supreme Chamber of Control, published in http://www. nik.gov.pl/plik/id,63,vp,63.pdf, p. 14 
In the theory of administrative law, agencies are often wrongly systematized. They can be divided according to their legal and organizational form. Because of the diversity of agencies, the unification of their formation procedures is not possible. Some of the agencies functioning as sole-shareholder companies of the State Treasury are formed by way of a notarial deed whereas other ones by way of a legislative act. The division of agencies according to formation procedure and legal basis makes it impossible to unambiguously classify them as public administration entities organized as public law entities (administrative offices and state juridical persons) or private law entities (sole-shareholder companies of the State Treasury). The doubts concerning proper classification of agencies among those entities stem from proper defining, for that is what enables one to place them among public or private entities. What is more, the actions undertaken by those entities take legal forms characteristic of both public and private law. In general, agencies can be considered untypical administering entities because of their eclectic legal nature which manifests itself in a mixture of administrative, civil and financial forms of organization as well as in the direct implementation of economic and social policies by the state. ${ }^{39}$

The foregoing analysis of Polish administrative law theory along with selected legal acts allows the conclusion that in the current legal situation the basic notions of administrative law need updating. In other words, administrative law (and administration itself) should be adapted to constantly changing social needs which force the state to create new organizational and legal forms. As a consequence, what is formed are organizations (institutions) derivative of typical public administration entities, though displaying elements of novelty. That is what makes them untypical (specific). It seems reasonable, however, to reflect on why the legislator forms them, for it is not always justifiable. Sometimes the Polish legislator senselessly transfers forms functioning in other countries into the Polish legal system forgetting about peculiarities of different systems. Hence some of organizations (institutions) are in advance doomed to failure or inefficiency in performing the tasks devolved upon them. It is therefore important to reach harmony between the state, its legal system, and satisfying needs of modern society.

39 Look at: K. Pawłowicz, Nietypowe podmioty administrujace w sferze gospodarki, (w:) Prawo gospodarcze. Zagadnienia administracyjnoprawne, red. M. Wierzbowski, M. Wyrzykowski, Warszawa 2001, p. 139. 